\title{
Middle Class: The Socio-Economic Stabilizer of the Country Development
}

\author{
Natalia Victorovna Kuznetsova ${ }^{1} \&$ Artemiy Yurievich Tupitsyn ${ }^{2}$ \\ ${ }^{1}$ Far Eastern Federal University, Russia \\ Correspondence: Natalia Victorovna Kuznetsova, Far Eastern Federal University, Russkii Island, v. Ayaks, 10, \\ Building 22 (G), 690950, Russia.
}

Received: May 26, 2013 Accepted: June 13, 2014 Online Published: August 28, 2014

doi:10.5539/ass.v10n17p278

URL: http://dx.doi.org/10.5539/ass.v10n17p278

\begin{abstract}
The article discusses the middle class impact on social and economic development of the society. It considers the modern middle class structure and functions both in social and economic fields of society life. Based on the data of international financial institutions, it analyzes the amount of middle class in the regions with the comparison of economic development of the country to discover the correlation between factors mentioned above. We have established that middle class impact on social and economic development of any country is huge and appeared in a number of factors. In addition, some of them have a direct influence on society development (economic indicators, standards of living, level of wages, etc.) while others have relative impact (middle class expenditures) In whole, middle class impact on social and economic development of the society in a country proceeds by stabilizing function of middle class, which is reached by implementation of little functional effects. Some of them have only economic influence, others have social impact. However, despite of the fact that they are applied separately, their close relationship forms the major indicators of middle class impact on socio-economic development of the society.
\end{abstract}

Keywords: middle class structure, middle class functions, impact indicators of the middle class, criteria for defining the middle class, criteria for country classification

\section{Introduction}

Beginning from the XVII - XIX centuries, the subject of the middle class was becoming more popular both in scientific environment and in the society. Different views and approaches to this theme allowed to evaluate from where the middle class was and when this layer was the most numerous. It is important because the middle class plays a great role in the development of the whole economy.

According to the large number of scientific and statistical studies, today the middle class is "niche" phenomenon rather than mass class. Its functions in the society are fundamental because middle layer is the major social and economic stabilizer. The middle class quantity and share in the country are preeminently those major indicators of socio-economic balance which determines the development of the whole society.

\section{Materials and Methods}

Due to the fact that middle class is the main social group in the developed countries, i. e. it is the core of the society, this is generally accepted to state about those functions the middle class holds there.

The function of social stabilizer is one of the most important roles middle class has. In the economic field middle class could be defined as "economic donor." From one point of view, in particular the middle class generates the main income items of the society: most part of the production power is located in this layer, including experienced workers of higher education, service providers, and businessmen who generate the main financial flows. Form the other hand, the middle class is a large consumer, tax bearer $(80 \%$ of all tax payments are middle class payments in the developed regions), employer and investor. However, the studies conducted by Asian Development Bank in India in 2011 (Chun \& Hasan, 2011) have shown that the middle class impact on resources consumption has indirect influence, and at the same time the correlation between the middle class and financial capital was observed. In addition, it was discovered that $60 \%$ of middle class consumption had a direct impact on production and manufacturing growth, which allows to state about middle class to be the major consumer of goods and services provided. 
In addition, the middle class is the basic supplier of labor force and workers with higher education, including different state officials and managers. At least, middle class also has a cultural function because it is the main keeper of cultural and social heritage. This function is called "the cultural integrator."

The middle class social impact could be described in social indicators. As a rule, the key criteria for middle class defining are:

1) the annual income of the population;

2) property availability;

3) daily expenditures per person are between 10 and 100 US dollars (Kyle, 2014).

In turn, the country classification according to its economic development includes three groups: developed (industrialized) counties, developing countries, and countries with transition economy.

There are no common criteria for country classification. However, despite of some general principles, classifications mentioned above use different approaches and indicators for estimation of economic development of any country.

In whole, the more rational approach is to classify countries according to the next criteria:

1) Gross national income per capita (GNI);

2) Field structure of the national economy (the production level).

In order to determine the economic development level, World Bank uses Atlas method, the kernel of which is to decrease the impact of small fluctuations of currencies exchange rate on the comparison process. This method takes into account the average measuring of exchange rate for the current year with the same indicators for two previous periods with inflation correction. The Atlas method is one of the most accurate and competent.

It should be noted that the provided method of country classification is simplified and aimed for comparison of economic development of the country with middle class share in it (see Table 1).

Table 1. Criteria for countries classification

\begin{tabular}{lccc}
\hline & $\begin{array}{c}\text { Developed } \\
\text { countries }\end{array}$ & $\begin{array}{c}\text { Developing } \\
\text { countries }\end{array}$ & $\begin{array}{c}\text { Countries with the } \\
\text { transitional economy }\end{array}$ \\
\hline GNI per capita, US dollars & 12616 - above & $4086-12615$ & $0-4085$ \\
Tertiary sector share in national economy, $\%$ & $60-100$ & $45-59$ & $0-44$ \\
\hline
\end{tabular}

Because middle class was firstly examined in the USA, today it is generally accepted to compare the economic development with the US economy, where middle class share is about $71.25 \%$ (the highest value in the world); i. e. from 319.9 million people about 228 million are middle class. The annual income of average American middle class individual is between 35,000 and 100,000 US dollars.

\section{Results}

According to the Atlas classification method by World Bank, the USA is developed country with the GNI per capita value of 50,120 US dollars (WB, 2013). About 47 million people (Kharas \& Gertz, 2010) are below poverty $(14,8 \%)$ (DeNavas-Walt, Proctor, \& Smith, 2012), while the average salary in 2012 was 45,790 US dollars.

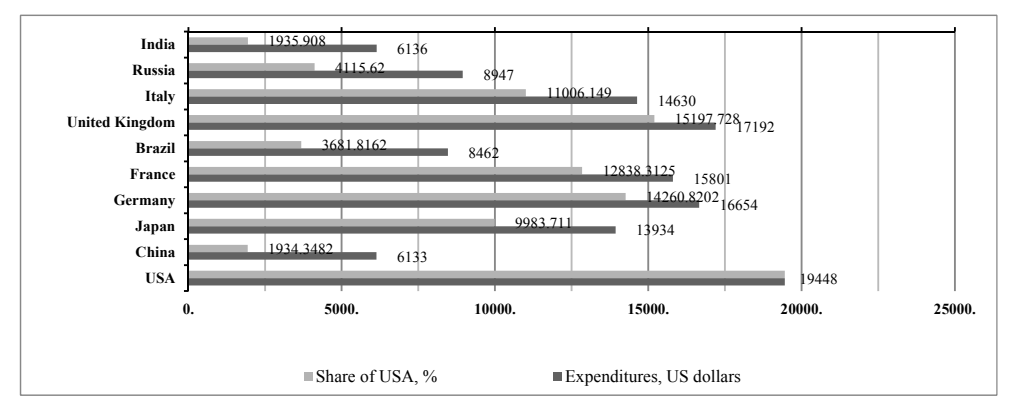

Figure 1. Middle class annual expenses per capita, 2011 (Kyle, 2014) 
In 2011 the average US middle class person spent about 19,448 US dollars (see Figure 1), and general expenditures of middle class this year were $35 \%$ of GDP.

As for the social factor, currently there is 155,6 million of labor force in the US (48.6\%), the unemployment rate is $3.5 \%$ (11,26 million people) [Economic News Release, 2013]. The Gini index equals to 0.48 . Expenditures per capita in the USA are 6,133 US dollars (see Figure 3), while the total spendings of middle class in 2011 were 1.183 billion US dollars, which is $12 \%$ of GDP.

We believe that the high developed economy of the US is those factor which predetermined the fast middle class formation in the USA. It allowed to establish high living standards there very fast and today the average income per capita is 7 times more than in the world (see Figure 2).

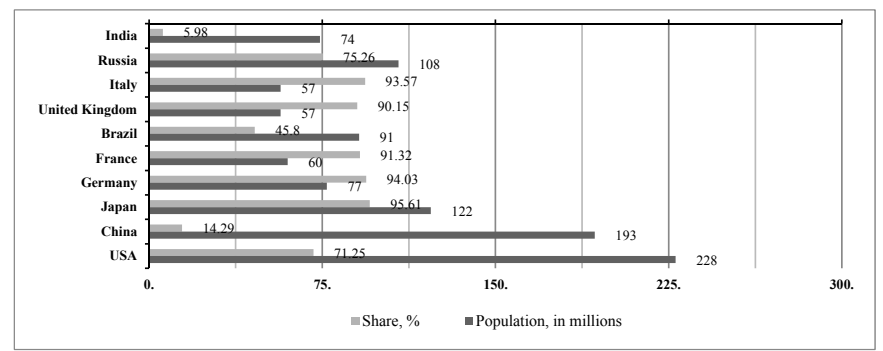

Figure 2. Middle class population and its share of the whole population, 2011

The next large country is People's Republic of China (PRC) which in absolute value of middle class population holds the second position in the world: there is 193 million people included to the Chinese middle class (see Figure 4). However, in relative value China is far behind still middle class share here is only $14.2 \%$. The average annual income is between 8,000 and 60,000 US dollars (in average $50 \%$ of the US indicator).

World Bank classifies China as developing country with GNI per capita of 5,740 US dollars (WB, 2013). China has the second most powerful economy in the world, but at the same time the middle class share in the population is one of the lowest in the world. We believe that such situation could be explained by cheap labor force, because form on hand China is the largest manufacturing region, but form another the Chinese salaries are one of the lowest among the developed and developing countries.

However, according to the study of large news company Global Post, in the future exactly developing countries would become the core of middle class development because of powerful economic system formation in such regions. According to the Figure 3, in 2030 the middle class population would increase up to 950 million people in China (68.2\% of total population). At the same time, in the US thus indicator is expected to be decreased by $15.85 \%$ (from $71.25 \%$ to $55.4 \%$ ) (WB, 2013).

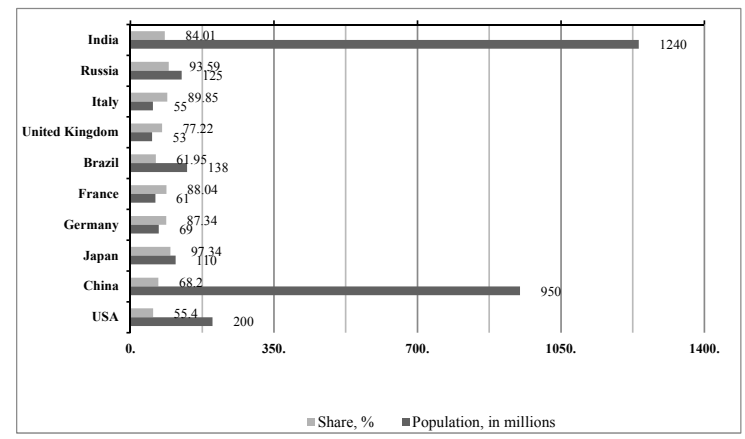

Figure 3. Forecast of middle class population and its share of the whole population, 2030 (Kyle, 2014)

Japan is another example which has the largest relative value of middle class share in the world (approximately 95.61\%). The annual middle class income per capita is between 10,000 and 30,000 US dollars, which is about $30 \%$ of the same US indicator. 
According to the Atlas method interpretation, Japan is highly developed region with GNI per capita of 47,870 US dollars. Tertiary sector share in the economy is $71.4 \%$ (425 million US dollars), manufacturing label is estimated to 1.15 billion US dollars.

The poverty level is $16 \%$ (20.4 million people), and middle class expenditures were 1.7 billion US dollars in 2011 which equals to $43 \%$ of Japanese GDP. It could be noted that middle class impact indicators in Japan on social and economic development is huge: approximately $96 \%$ of population is identified as middle class, and $54 \%$ of them is labor force, employed in the manufacturing (secondary) sector, $69.8 \%$ in the tertiary sector, and $3.9 \%$ in the primary sector (agriculture) (Latest indicators, 2011). It allows the Japanese middle class to generate approximately $90 \%$ of GDP which equalled to 5,367.5 billion US dollars (CIA World Factbook, 2014).

These values are reached because of Japanese middle class expenditures (see Figure 4) which in 2011 were 1,701 million US dollar in Japan (73\% of GDP value) (China - New Global, 2012). The Chinese middle class spent 1,183 million dollars, but this value was reached because of Chinese numerous population (quantitative indicator) rather than of other qualitative values. The Chinese middle class annual expenditures per capita are 6 thousand US dollars versus 14 thousand of Japanese middle layer, and the USA has the largest value of 19.5 thousand US dollars which is $68 \%$ more than in China and 28\% that in Japan. Only Western European countries have these values that close the US indicators.

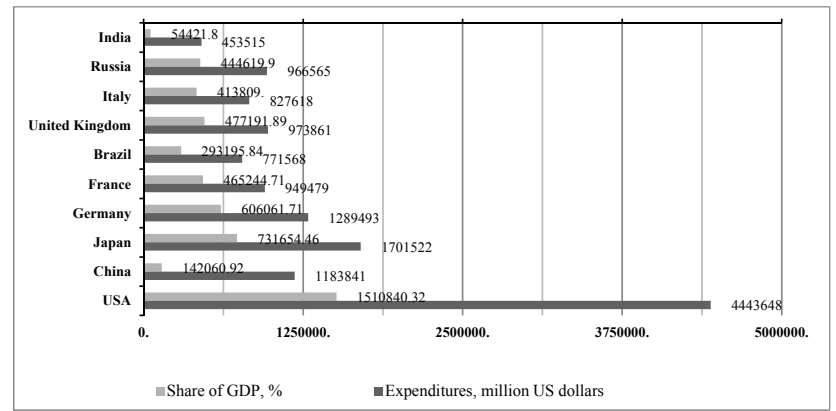

Figure 4. The aggregate expenditures of middle class by regions and share of GDP, 2011

There is no large fluctuation in middle class variety by country in Western Europe. For instance, in relative value the most developed countries like Germany, France, United Kingdom, and Italy have the average middle class share equalled more than $90 \%$ of local population.

In France the average income per capita of middle class representative is $15,000-20,000$ US dollars ( $52 \%$ of the US indicator), in the UK the same indicator is equalled to $25,000-35,000$ US dollars (44\% of the US value).

According to the Atlas method by World Bank, both France and UK are highly developed regions with GNI per capita of 41,750 and 38,250 US dollars, respectively.

There is $8.8 \%$ of French population is below the poverty line (5.8 million people), and $16 \%$ of the UK population (10.1 million people). The unemployment rate is $10.5 \%$ in France (6.8 million people) and $7.6 \%$ in the UK (4.8 million people).

The middle class average annual expenditures per capita in 2011 were 15,801 US dollars for the French middle class.

On the basis on the indicators analyzed for the developed countries, it could be concluded than middle class is the generator of economic and social development because of the next factors:

1) the middle class share of the whole population is above $90 \%$;

2) the tertiary sector share in the economy is above $70 \%$;

3) GNI per capita is above 40 thousand US dollars;

4) the average income per capita is above 15 thousand US dollars.

China takes the particular position in this analysis because in absolute values it holds the second position in the world but not in relative indicators. However, according to forecasts, in 2030 the share of the Chinese middle 
class would increase up to 950 million people which could allow middle layer to become the main source of economic and social growth of this largest Asian country.

India is the other similar example. In 2011 there were about 1.237 billion people, 74 million of whom (5.98\%) are corresponded to the middle class criteria. Approximately 270.9 million people were below poverty line (21.9\%) (CIA World Factbook, 2014). The average income per capita was from 3,000 to 6,000 US dollars which is equalled to $5 \%$ of the similar US indicator.

The average middle class expenditures per capita in 2011was 6,136 US dollars (Child Labour In India, 2011), while the total sum was estimated to 453 million US dollars (12\% of GDP) (Report on Employment, 2010).

In total population India holds the second position in the world, but it has the lowest middle class share at the same time. That is why it is hardly possible to objectively evaluate the Indian middle class impact on the social and economic development of the society.

According to the different evaluations, the middle class share in Russia, is estimated to $75 \%$ (108 million people), from which $11.2 \%$ are below poverty line (15.8 million people) (Poverty rate in Russia, 2013). The unemployment rate was $5.4 \%$ in 2013 (approximately 7.77 million people) (Labor Force, 2013). The total amount of labor force was 75.5 million people, $4.4 \%$ of whom were employed in the agriculture sector, $37,6 \%$ in the secondary sector, and $58 \%$ in tertiary sector (GDP composition, 2012).

The annual income per capita in 2011 was $6,000-24,000$ US dollars ( $22 \%$ of the US value) and the total expenditures were 966,565 million US dollars (8,947 US dollars per capita).

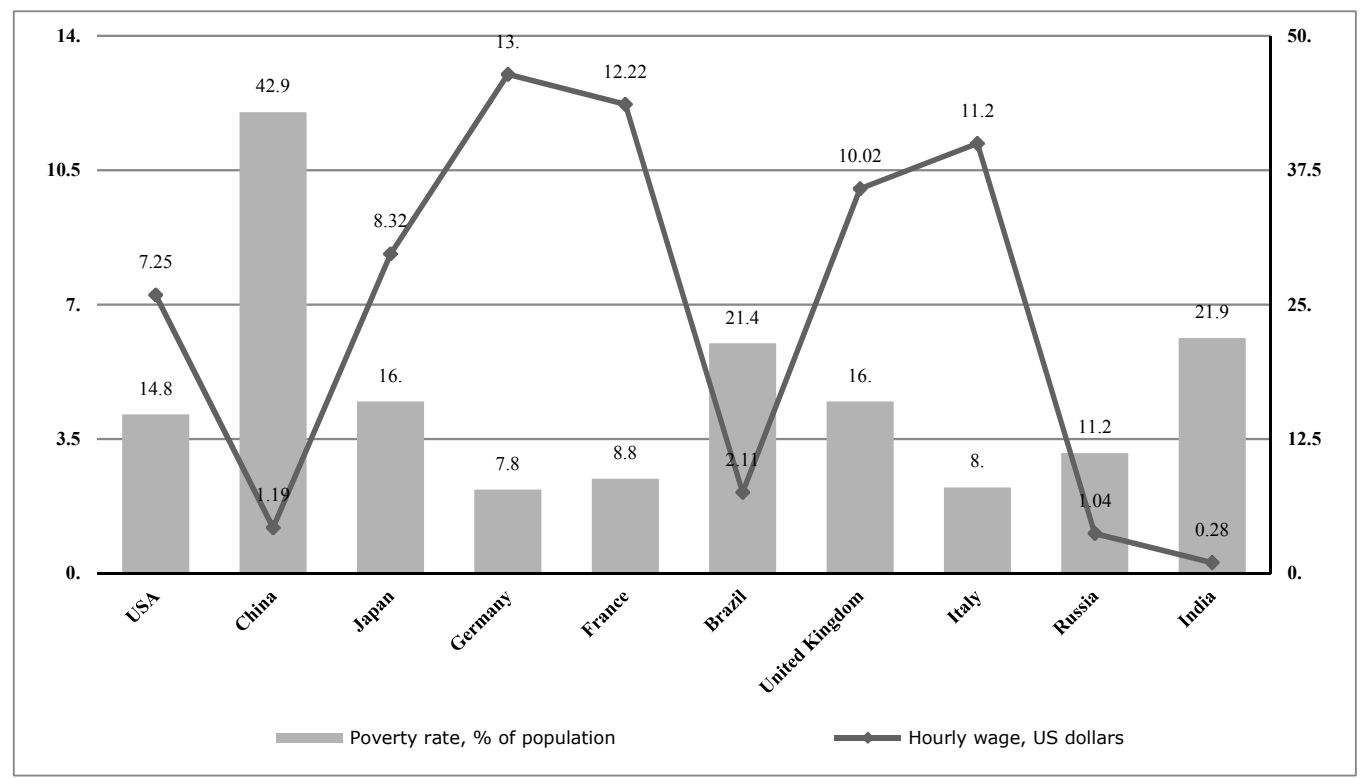

Figure 5. Minimal hourly wage and poverty rate, 2011-2012

\section{Discussion}

According to the opinion of some researchers, the development of any country is always accompanied by scientific or technology breakthrough: they see the middle class to be the major source of these resources. There is a direct correlation between socio-economic development of the country and the middle class formation because the more numerous middle class is the more developed stage region achieves. The famous French sociologist M. Halbwachs believed the middle class to be the major source of industrial development of the European countries. In addition, he proposed that the key criterion of this development was in "technical activities" (Halbwachs, 2000). Another researcher, P. Florida, agreed with him and offered three T concept that includes combination of such factors as technology, talent, and tolerance (Florida, 2007). Later, this fundamental position was confirmed by new researches of such scientists as Z. Bauman (Bauman, 1998). 
At the same time, the range of other researches (Milanovic and Yitzhaki, 2002; Kessler and Virgillo, 2010) don't share this position. They state about total absence of the middle class in the society forming by this reasons for the further discussions.

Thus, the diversity of scientific views causes barriers to the common study of the modern middle class problems, which is too important for the society development concept. Often its role in socio-economic development of the country remains underestimated, and the main reasons of this situation are both the numerous views on middle class formation, structure, and functions and the poor development of this social layer in many parts of the world We believe the importance of the middle class research to be ridden by the irregular formation and development of this social layer in different countries because in some regions the middle class is powerful socio-economic stabilizer while others almost completely absent the middle class and its influence on the country development. Such situation gives rise to the opposite views on this subject among the scientific community. That is why the most important methodological and practical issue lies in the studies unification in order to determine the common approaches to the middle class problems. In the future it will allow to clearly identify the role of the middle class in socio-economic development of the society.

\section{Conclusion}

In the cases analyzed it could been noticed that middle class impact differs from the country of study. For instance, middle class has no any impact on Indian development not only because of its tiny share in the population, but also low level of economic and social development. In opposite, in such regions as the USA, Japan, Germany, France, the UK and Italy the poor population share is low (from 7.8\% to $14.8 \%$ ), and minimal hourly wage is quite high which allows these countries to have large middle class share. As a result, there middle class is that unit between the Government and social and economic life of society, which predetermined development of these regions.

\section{References}

Bauman, Z. (1988). Postmodernism as social theory: Some challenges and problems. Theory, culture \& society. Cleveland, 5(2-3), 217-238. http://dx.doi.org/10.1177/0263276488005002002

Chun, N., Hasan, R., \& Ulubasoglu, M. (2011). The Role of the Middle Class in Economic Development: Why Do Cross-Country data show? ADB Economics Workin, Paper Series, 245, 40. Asian Development Bank.

CIA World Factbook: Japan. (2014). Central Intelligence Agency. Retrieved February 22, 2014, from http://www.cia.gov/library/publications/the-world-factbook/geos/ja.html

China - New Global Poverty Estimates. (2012). World Bank. Retrieved May 2, 2013, from http://povertydata.worldbank.org/poverty/country/CHN

Child Labour in India. (2011). Child Line. Retrieved February 13, 2013, from http://www.childlineindia.org. in/child-labour-india.htm

DeNavas-Walt, C., Proctor, B. D., \& Smith, J. C. (2012). Income, Poverty, and Health Insurance Coverage in the United States: 2011. U. S. Census Bureau (p. 81).

Economic News Release: Employment Situation Summary. (2013). Household data, seasonally adjusted. Retrieved November 13, 2013, from http://www.bls.gov/news.release/empsit.a.htm

Florida P. (2007). Creative class: Individuals that change the future (p. 421). Classica-XXI publishing house.

GDP composition, by sector of origin. (2012). Central Intelligence Agency. Retrieved December 12, 2013, from http://www.cia.gov/library/publications/the-world-factbook/fields/2012.html

Halbwachs, M. (2000). Social classes and morphology (p. 510). SPB: Aleteya.

Kessler, G., \& Di Virgillo, M. (2010). Impoverishment of the middle class in Argentina: The 'new poor' in Latin America. Laboratorium, 2(3), 200-220.

Kyle, K. (2014). Global Post. Measuring the middle class of the world's top 10 economies. Retrieved February 24, 2014, from http://www.globalpost.com/measuring-the-middle-data-interactive

Kharas, H., \& Gertz, G. (2010). The New Global Middle Class: A Cross-Over from West to East (p. 396). Washington: Wolfensohn Center for Development at Brookings, Brookings Institute.

Latest indicators. (2011). Statistics Bureau, Ministry of Internal Affairs and Communications. Retrieved November 24, 2013, from http://www.stat.go.jp/english/index.htm

Labor Force at the End of the Month in Russia. (2013). Federal State Statistics Service. Retrieved December 13, 
2013, from http://www.gks.ru/bgd/free/B00_25/IssWWW.exe/Stg/d000/I000040R.HTM/

Milanovic, B., \& Yitzhaki, S. (2002). Decomposing world income distribution: Does world have the middle class? The Review of Income and Wealth, 48(2), 155-178. http://dx.doi.org/10.1111/1475-4991.00046

Poverty rate in Russia went down in 2012 - Russia's Statistics Agency. (2013). Russia beyond the headlines. Retrieved December 10, 2013, from http://rbth.com/news/2013/03/25/poverty_rate_in_russia_went_down_ in_2012_-_russias_statistics_agency_24208.html

Report on Employment \& Unemployment Survey (2009-10). (2010). Government of India Ministry of Labour \& Employment. Labour Bureau Chandigarh, 8(October), 161.

World Bank. (2013). GNI per capita, Atlas Method (current US\$). Retrieved February 3, 2014, from http://data.worldbank.org/indicator/NY.GNP.PCAP.CD

\section{Copyrights}

Copyright for this article is retained by the author(s), with first publication rights granted to the journal.

This is an open-access article distributed under the terms and conditions of the Creative Commons Attribution license (http://creativecommons.org/licenses/by/3.0/). 